\title{
Online harassment in Japan: Dissecting the targeting of a
}

\section{female journalist [version 1; peer review: 1 approved, 1}

\section{approved with reservations]}

\author{
礪波亜希 (D)1、吉田光男 (D)1、佐野幸恵 (D)2 \\ 1筑波大学ビジネスサイエンス系, 日本 \\ 2筑波大学 システム情報系, 日本
}

\author{
Aki Tonami (id), Mitsuo Yoshida (id), Yukie Sano (id) \\ ${ }^{1}$ Faculty of Business Sciences, University of Tsukuba, 3-29-1 Otsuka, Bunkyo, Tokyo, 112-0012, Japan \\ 2Faculty of Engineering, Information and Systems, University of Tsukuba, 1-1-1 Tennodai, Tsukuba, Ibaraki, 305-8577, Japan
}

V1 First published: 17 Nov 2021, 10:1164

https://doi.org/10.12688/f1000research.74657.1

Latest published: 03 Feb 2022, 10:1164

https://doi.org/10.12688/f1000research.74657.2

要旨

ソーシャルメディア上の「炎上」はもはや社会問題といっても過言ではな いが、日本語環境の炎上については、被害にあった当事者視点に基づいて 検討した研究は稀少である。本稿では、オンライン・ハラスメントという 概念を導入し、その現状を国内外の先行研究のレビューに基づいて概要を 明らかにした。次に、Twitterで発生した女性記者ツイートの「炎上」事 例を分析、ハラスメントを行うユーザーにはインフルエンサー群、インフ ルエンサーの犬笛に呼応する炎上加担ユーザー群、荒らしを行うユーザー 群の三層があり、それぞれが異なる形で一人のユーザーに対してハラスメ ントを行っていたことを観察した。最後に、個人と組織が取るべき対策を 述べる。

Abstract

Harassment on the Internet, particularly on social media such as Twitter, has reached a level where it can, without exaggeration, be characterised as a real-world societal problem in Japan. However, studies on this phenomenon in the Japanese language environment, especially adopting a victim-centric perspective, are rare. In this paper, we incorporated the concept of online harassment and reviewed existing studies about online harassment from Japan and abroad. We then conducted a detailed case analysis of the "flaming" of

\section{Open Peer Review}

Approval Status

1

2

version 2

(revision)

03 Feb 2022

version 1

17 Nov 2021

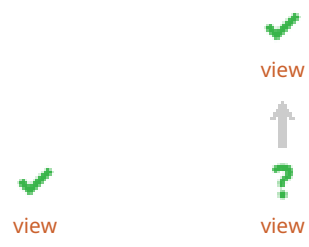

1. Yasuko Kawahata, Rikkyo University, Tokyo, Japan

2. Shinichi Yamaguchi ID, International University of Japan, Niigata, Japan Any reports and responses or comments on the article can be found at the end of the article. 
a female journalist and those who targeted her on Twitter. Based on our analysis, we observed that there were three layers of users who targeted the journalist: influencers, users who responded to the instigation by influencers, and trolls. Each harassed the journalist, but in a different manner. Given Japan's particular difficulty of imposing domestic regulations on social media companies that are mostly from abroad, we propose and describe possible measures that individuals and their employers should consider taking.

Keywords

ソーシャルメディア, オンライン・ハラスメント, Twitter, 政策, social media, online harassment, policy, COVID-19

This article is included in the Japan Institutional

v JAPAN Gateway gateway.

Corresponding author: Aki Tonami (tonami.aki.ka@u.tsukuba.ac.jp)

Author roles: Tonami A: Conceptualization, Data Curation, Formal Analysis, Funding Acquisition, Investigation, Methodology, Project Administration, Resources, Software, Visualization, Writing - Original Draft Preparation, Writing - Review \& Editing; Yoshida M: Formal Analysis, Investigation, Methodology, Writing - Review \& Editing; Sano Y: Data Curation, Investigation, Visualization, Writing - Review \& Editing

Competing interests: No competing interests were disclosed.

Grant information: This work was supported by Japan Society for the Promotion of Science (JP20K01496, JP20K19928), JST-Mirai Program (JPMJMI20B4) and University of Tsukuba Gateway (F1000) Article Submission Support Program, Faculty of Business Sciences, University of Tsukuba.

The funders had no role in study design, data collection and analysis, decision to publish, or preparation of the manuscript.

Copyright: ( $\subset 2021$ Tonami A et al. This is an open access article distributed under the terms of the Creative Commons Attribution License, which permits unrestricted use, distribution, and reproduction in any medium, provided the original work is properly cited.

How to cite this article: Tonami $\mathrm{A}$, Yoshida $\mathrm{M}$ and Sano $\mathrm{Y}$. Online harassment in Japan: Dissecting the targeting of a female journalist [version 1; peer review: 1 approved, 1 approved with reservations] F1000Research 2021, 10:1164 https://doi.org/10.12688/f1000research.74657.1

First published: 17 Nov 2021, 10:1164 https://doi.org/10.12688/f1000research.74657.1 


\section{はじめに}

近年、デジタル技術が進展し、ソーシャルメディア ${ }^{1}$ (SNS) が普及することにより、多くの人が簡単に情 報発信や収集を行うことが可能となった。また 2019 年に発生した新型コロナ感染症 (COVID-19) の感染 拡大と、政府の緊急事態宣言を受け、できるだけ外出や対面を控えるため、人々がインターネットを利用 する頻度も顕著に高まった（森下，2021）。同時に、インターネット上のトラブル、とりわけSNS上におけ るコミュニケーション不全に関する事件が多発している。いわゆる「ネット炎上」はもはや社会問題と いっても過言ではない。「炎上」とは、ある人物が発言した内容や行った行為について、ソーシャルメ ディアに批判的なコメントが殺到する現象を意味する（山口, 2015）。

しかしながら、炎上に関する既存研究は、SNS 上における情報の現象について扱うものが多く、とりわけ 日本語環境の SNS については、炎上の被害にあった当事者視点に基づいて検討した研究は稀少である。 そこで本稿では、炎上現象を検討する際に、オンライン・ハラスメントという概念を導入する。オンライ ン・ハラスメントとは、「インターネット上で行われる、扇情的なコメントやへイトスピーチの繰り返し の投稿(「荒らし」「トロール」)、サイバーストーカー、身体的な脅迫、同意なしに性的に露骨な画像を 公開すること(「リベンジポルノ」)、個人情報を公開する(「晒し」「ドクシング」)などの行為」を意味する (PEN America, n.d.-b)。

本稿ではまず、オンライン・ハラスメントの現状を先行研究のレビューに基づいて概要を明らかにし、 次に、日本で約 5,500 万人が使用する SNS である Twitter で発生した、女性記者ツイートの「炎上」、お よびオンライン・ハラスメントの事例分析を行う (Statista Research Department, 2021)。最後に、個人と組 織が取るべきオンライン・ハラスメント対策について述べる。

\section{オンライン・ハラスメントの現状}

オンライン空間において、どのようなハラスメントがどの程度行われているのであろうか。オンライン・ハ ラスメントは、デジタル技術やSNS が社会にもたらした負の影響であるといえるが、既存のデジタル技術に 関する研究はこうした負の変化に楽観的であったことも関係して、オンライン・ハラスメントに特化した大 規模な調査は多くはない (Fung et al., 2013; Jankowicz et al., 2021)。子どもの権利を推進する国際 NGO である プラン・インターナショナルの 2020 年の調査によれば、日本の 15 24 歳の若年女性 501 名のうち、 $25 \%$ \%が 「SNSで何らかの形でオンライン・ハラスメントを経験したことがある」と回答したという(プラン・インタ 一ナショナル, 2020)。他方、31 カ国で行われた調査結果を比較したところ、各国でオンライン・ハラスメン トの概念について理解が異なること、回答者によっては全く理解されていないことも明らかとなった。

米国・ピュー研究所による 2021 年の調査報告書によれば、米国人の 4 人に 1 人がオンライン・ハラスメント を受けたことがあり、このうち半数が政治的な意見を理由にハラスメントを受けたと答えた (Vogels, 2021)。ま た、2014 年、2017 年の同様の調査に比して、身体的な劦迫や、ストーキング、継続的なハラスメント、セクシュ アル・ハラスメントなど、より深刻なオンライン・ハラスメントを受けたと答えた人数が増加したという。

日本語環境については、インターネットプロバイダーの BIGLOBE社による全国の 20 代〜 60 代の SNS を利用 する男女 770 人に対する調査において、SNS で他者から誹謗中傷ををされたことがあるかとの質問に対し、 4.5\%が「よくある」、13\%が「たまにある」と返答した (BIGLOBE株式会社, 2020)。なかでも20代は年代別 で最も顕著に誹謗中傷を受けた比率が高く、10\%が「よくある」、18.9\%が「たまにある」と回答したとい う。ただしここでの誹謗中傷はオンライン・ハラスメントの定義とは異なるため、注意が必要である。誹 謗中傷とは、誹謗 (他人の悪口を言うこと)と中傷（根拠のない悪口を言い、他人の名誉を傷つけること）の 2 つが合わさった語である（三省堂, 2013）。炎上とは、前述のとおり、誹謗中傷を含む批判的なコメントがソ ーシャルメディアに殺到する現象のことで、オンライン・ハラスメントは、誹謗中傷を含むハラスメント 行為がオンライン上で行われることであり、時にその行為は集中的に行われ、炎上現象にもなり得る。

オンライン・ハラスメントの全容を明らかにする試みとは別に、被害者の回復支援を優先したアプローチ で行われた調査結果が存在する。文筆従事者の団体、国際ペンクラブの米国支部 PEN アメリカでは、記

${ }^{1}$ 個人、コミュニティ、組織が、簡単にアクセスできるユーザー生成コンテンツを作成、共同作成、修正、共有、関与するこ とを可能にすることで、共同作業、接続、相互作用、コミュニティの構築を可能にする Web ベースのサービスのこと (McCayPeet \& Quan-Haase, 2017)。

2 同調査では、「根拠のない悪口を言いふらして他者の名誉を傷つけたり、人格を否定するような言葉で他者を傷つけるこ と」と定義されている。 
者やライターなどが SNS で梁刻なハラスメントに遭っていることを重く見て、「オンライン・八ラスメン トフィールドマニュアル」という調査研究事業を開始した (PEN America, n.d.-c)。同団体が 2017 年に実施 した調査によれば、オンライン・ハラスメントを受けた 230 名から回答があり(うち 196 名は性別の明記 があり、136 名が女性、52 名が男性、8 名がその他)、インターネット上で発生したオンライン・ハラス メントが、被害者の実生活に深刻な影響を及ぼしていることが明らかとなった。例えば、67\%の回答 者が「自分や身近な人の身の危険を感じたり、作品の発表を控えたり、SNS のアカウントを永久に削除 するなど、深刻な反応を示した」、64.3\%が「ハラスメントを理由に SNS を休止した」、62.3\%が「オン ライン・ハラスメントが私生活や身体的、心理的、精神的な健康に影響を及ぼした」と答えている (PEN America, n.d.-b)。また、ハラスメントを受けた理由としては、53.5\%が「自分の政治的見解を述べたた め」、「個人的な意見を述べたため」、38.9\%が「性別や性自認を理由に標的にされた」、31\%が「外見 (ルッキズム)」と回答しており、オンライン・ハラスメントが SNS 上で個人が意見表明を行ったこと、も しくは発言者のジェンダーやアイデンティティを理由に行われていることが分かる。

また、研究成果公開活動や、研究者同士のネットワーク拡大、また学生とのコミュニケーション促進の一 助として、ソーシャルメディアの使用が奨励されている場合が多い大学界においても、研究者がオンライ ン・ハラスメントの被害に頻繁に遭い、有害な影響が出ていることが指摘されている。ゴッセら (2021) は、オンライン・ハラスメントは仕事、アイデンティティ、もしくは学者としての必要条件のように見な されているものの、ジェンダー、外見 (ルッキズム)の要素が絡まることで複雑化していると述べた。

ソビエラージ (2020) によれば、オンライン・ハラスメントは誰でも被害に遭う可能性があるが、特に加 害者の標的になりやすい属性があるという。すなわち、

1) マイノリティである、

2) フェミニスト（旧来のジェンダー価值観に縛られない)である、

3）政治、スポーツ、外交、防衛、サイバーセキュリティなど男性優位の領域について意見する

場合、ハラスメントの標的になりやすく、これらの属性の共通部分においては最もハラスメントに遭う確 率が高くなる(図 1)。なお、欧州の調査では、女性議員の $58.2 \%$ 。 SNS 上でオンライン・八ラスメントを 受けたことがあると返答したが、特に年齢の低さ (40歳以下)、次に野党党員であることなど、議会政治 において少数派である側面がハラスメントに遭うリスクを高めるとの結果であった (Inter-Parliamentary Union, 2018; 申・濱田, 2021)。

米国のオンライン・ハラスメント被害者の支援団体であるオンライン SOS による報告書によると、オン ライン上のハラスメントはインターネットの商業化が進んだ 1990 年代から存在していたが、2014 2016 年の「ゲーマーゲート」3期を経て、2016 年米国大統領選挙において一連のハラスメントの流れが確立した (Lee，2019)。すなわち、悪意をもつ行為者が、様々な方策を使用し、多数の媒体を通じて、複数の場所 で、標的 (被害者)に危害を与えるメカニズムが存在するのだという(図 2)。このように、最近の研究で は、オンライン空間におけるハラスメント行為であっても被害者の受ける影響は甚大であること、また八 ラスメントや様々な暴力行為がオンライン空間ではなく、オフライン、すなわち現実世界に繋がることが 問題視されている (Berry, 2019)。

こうしたオンライン・八ラスメントに対して、SNS プラットフォームはどのように対処しているのだろ うか。ヤンコビッチら (2021) は、Facebook, Twitter, YouTube などユーザー数の多いSNSプラットフォー ムは、利用規約や「コミュニティ・ガイドライン」にハラスメント防止指針を取り入れているが、オンラ イン・ハラスメントの実態に比して画一的で、不十分であると指摘している。先述の PEN アメリカの調 査においても、オンライン・ハラスメントを経験した 230 名のうち、 $53.1 \%$ オ゙ハラスメント被害をプラッ トフォームに通報したことがあると回答し、そのうち $70.8 \%$ ゙プラットフォーム側の対応は全く役に立た なかった、と回答している。

${ }^{3} 2014$ 年夏頃から欧米で発生した、表現の自由を掲げるゲーム愛好者と、女性差別の観点から表現規制を求めるフェミニスト らの対立がインターネット上で激化した事件。特定の女性プログラマーに対し、個人情報の流出、殺害予告、脅迫を含む過 激なオンライン・ハラスメントが行われた。 


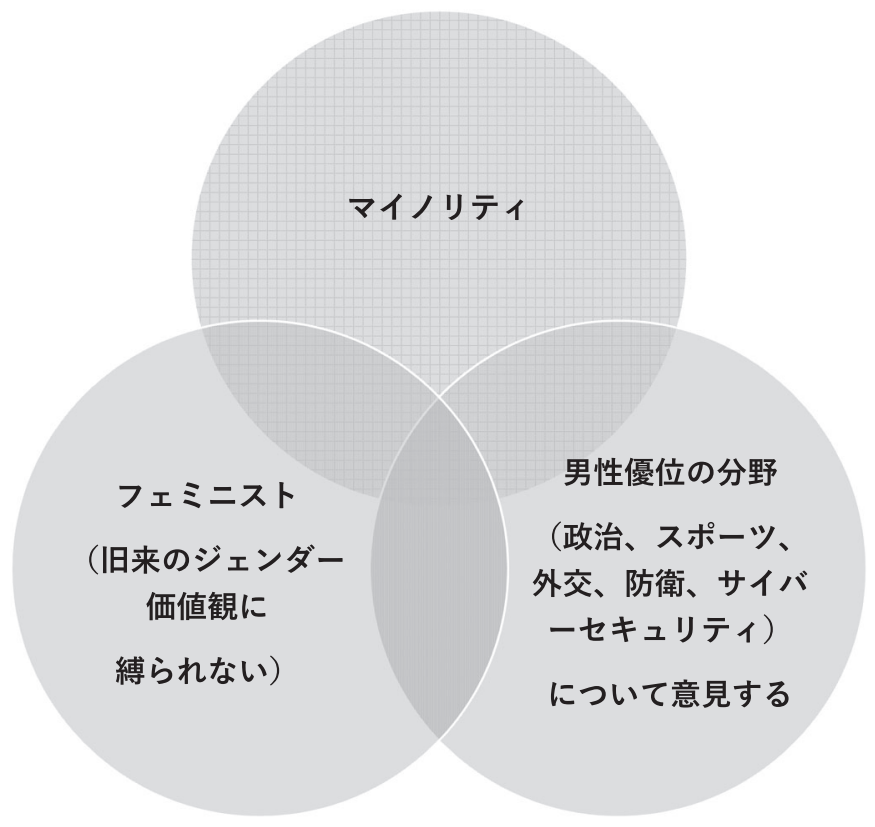

図 1. オンライン・ハラスメントの被害に遭いやすい属性 (Jankowicz et al (2020)より).

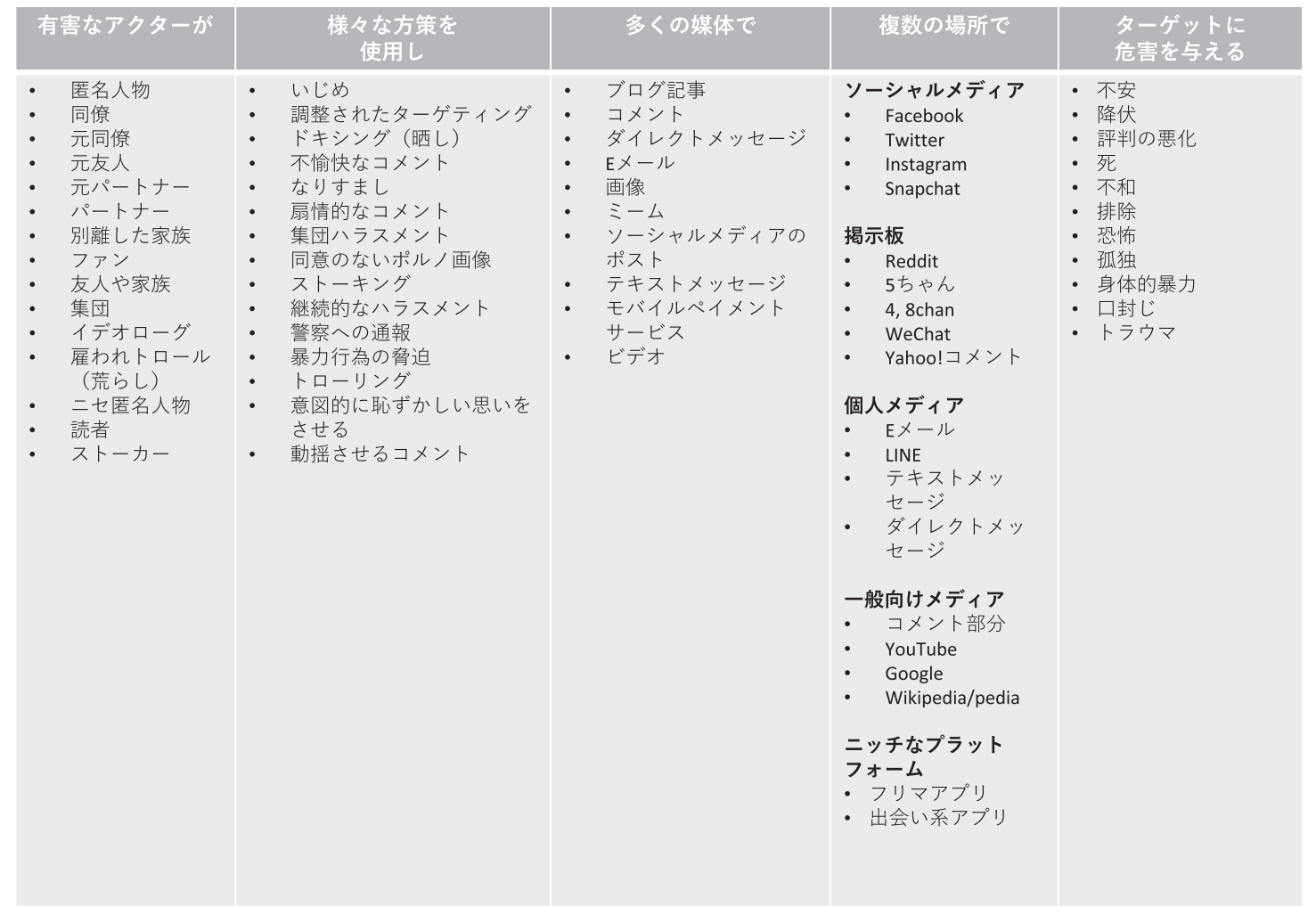

図 2. オンライン・ハラスメントの構成要素 (Lee, 2019) に基づく. 
これらの既存研究は主に欧米の言語環境におけるオンライン・ハラスメントを分析したものである。そこ で本稿では、事例分析を通じて、日本語環境におけるオンライン・ハラスメントの被害とメカニズムの一 例を詳述することを試みる。

\section{事例分析 : X社の記者ツイート「炎上」事件}

本稿では、質的アプローチを用い、事例分析を行った。研究パラダイムとしては、解釈主義に基づく。 分析対象とした Twitter アカウントは、大手メディア企業（以下X社とする）に所属する実名の女性記者の アカウント (以下Z氏) で、約 2 万のフォロワーを持ち、Twitter 社にも著名人であるという認証を受けてい る。筆者は、Twitter を使用し、従前より同アカウントをフォローしており、そのため同アカウントが以 前に「炎上」の被害を受けていたことを確認していた。分析対象とした事例は、新型コロナウイルスによ る死者数の多頞に関するツイートの掲載を発端とする炎上であるが、本ツイートがなされた時期は日本で も過去最多の新規感染者数が記録されていた頃であった（日本経済新聞, 2021)。このことも関係してか、 後述するとおり、本ツイートは多数のユーザーによって引用を含むリツイートがなされ、筆者らの目にも 入ることとなったため、事例分析の対象として選択した。

$\mathrm{Z}$ 氏は、 2021 年 8 月 3 日午後 7 時 12 分に、新型コロナ感染症拡大による死者の数について、これを少ない と表現するツイート等を見ると悲しくなる、数の多寡にかかわらず、亡くなった人一人ひとりに人生があ り、それを「少ない」などと特に著名人が矮小化するのはいかがなものか、という内容のツイートをした。

本ツイートは掲載後、約 3 日間にわたり批判的なツイートが集中し、炎上状態となった。本稿では、2021 年 8 月 3 日 7 日の間にZ氏アカウントに直接届いた 2,817 件の直接リプライ (直接リプライ 1,175 件、こ れらのリッイート1,499 件、引用リッイート 143 件)、及び 5,595 件の本ツイートの引用リッイート(以下 引用 RT)の分析を行った。データ分析対象ツイートは、ExportData.io サービスを利用し、(to:[Z 氏のアカ ウントID]）until: 2021-08-07 since: 2021-08-03 および Query: https://twitter.com/[Z氏のアカウントID]/status/ 1422500544032038919, Result type: mixed, Language: ja で 2021 年 8 月 7 日に取得した。なお、同等の機能を 果たす無料の代替品には、Twitter の公式 API (https://developer.twitter.com/en/products/twitter-api、ないし https://developer.twitter.com/en/docs/twitter-api/tools-and-libraries) がある。

なお、直接リプライを中心に分析を行うのは、仮に引用RTが拡散されても、被引用ユーザーには通知が 届かず、静観できる状況であるものの、被引用ユーザーに対して直接リプライ、もしくは引用 RT がなさ れると、本人に通知が届き、とりわけそのコメントが被引用ユーザー本人のアイデンティティ等、元ツイー トの内容以外について批判的なコメントであった場合、ハラスメント行為に直面することとなり、精神的 苦痛が大きいためである。

図３はZ氏アカウントへの直接リプライ及び直接リプライをリツイート、引用 RT したツイートの 時間当たりの数をグラフ化したものである。これからは、一時間あたり直接リプライの数が、 8 月 3 日午 後 11 時台に一度ピークを迎え、低下した後、翌 8 月 4 日午後4時台から再び急増し、午後 9 時台になるま で、一時間あたり優に 100 近くのリプライが届く状態が継続したことが分かる。質的分析ソフト NVivo Windows（2020 年 3 月リリース版）を使用して、直接リプライの感情を自動で分類したところ、図 4 のよ うになり、大部分の直接リプライが批判的な内容であることが判明した。なお同等の機能を果たすフリー の代替品として、KH Coder 3 や、Python のライブラリML-Ask がある。これらを用いることで、ツイート に現れる単語の出現頻度や感情を分析することができる。

さらにツイートを手動で分類したところ、1,175 件の直接リプライのうち、肯定的な内容は 147 件、批判 的な内容は 1,022 件となっていた。また、同ソフトを使用してワードクラウドを作成したものが、図 5 である。図からは、直接リプライを送った者は「日本における（新型）コロナ（ウイルス感染症）による 死者数は少ない」という旨を主張していることが分かる。

直接リプライを手動で分類したところ4、表 1 のとおりであった。最も数の多かった元ツイートの内容に 対する主張は、「(死者数が) 少ないという表現は妥当である」というもので (216 件)、次は「(新型コロ

\footnotetext{
${ }^{4}$ 同一ツイートに複数のコードが含まれる場合もある。
} 
300
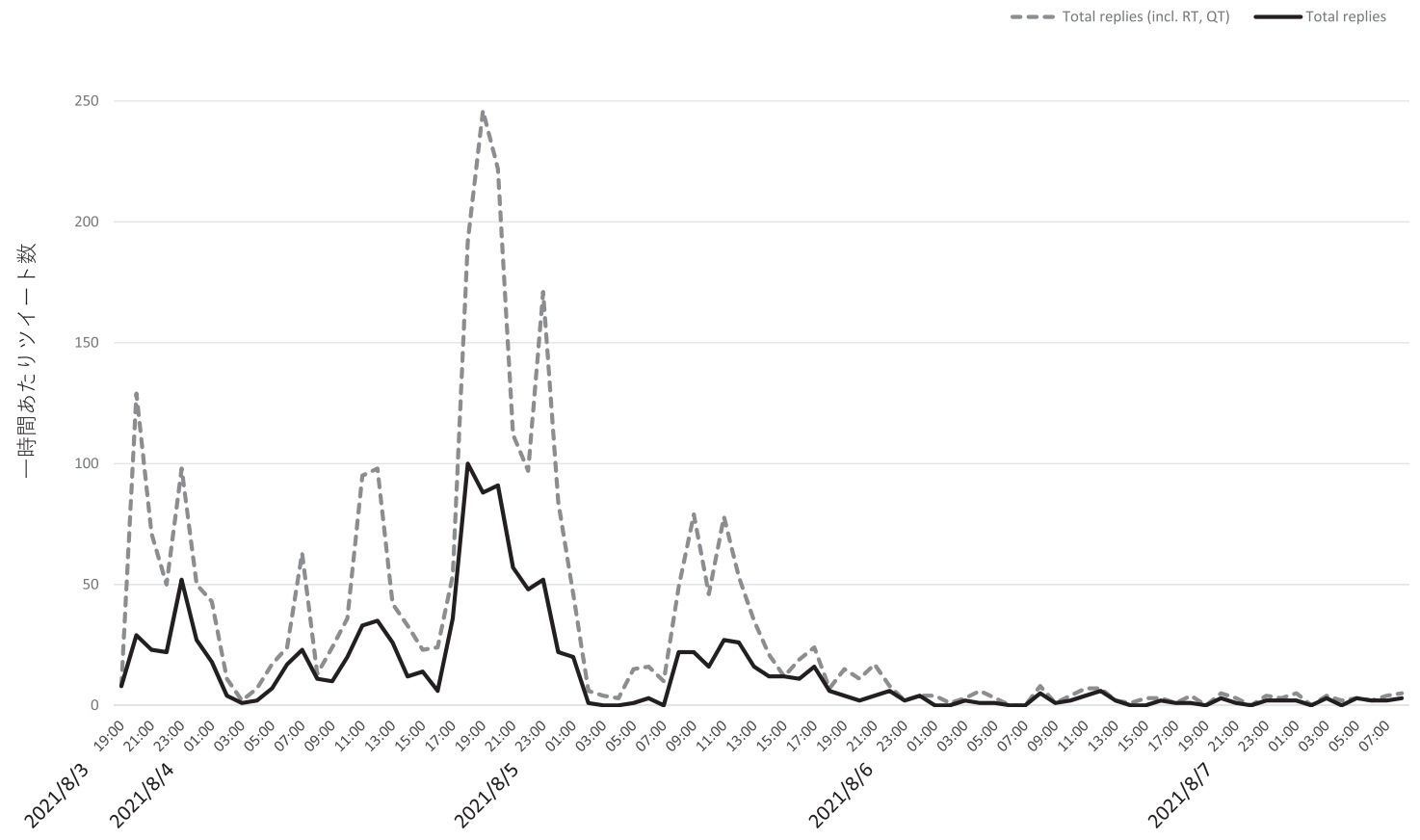

図 3.一時間あたり直接リプライおよびそれらのリツイート、引用 RT 数.

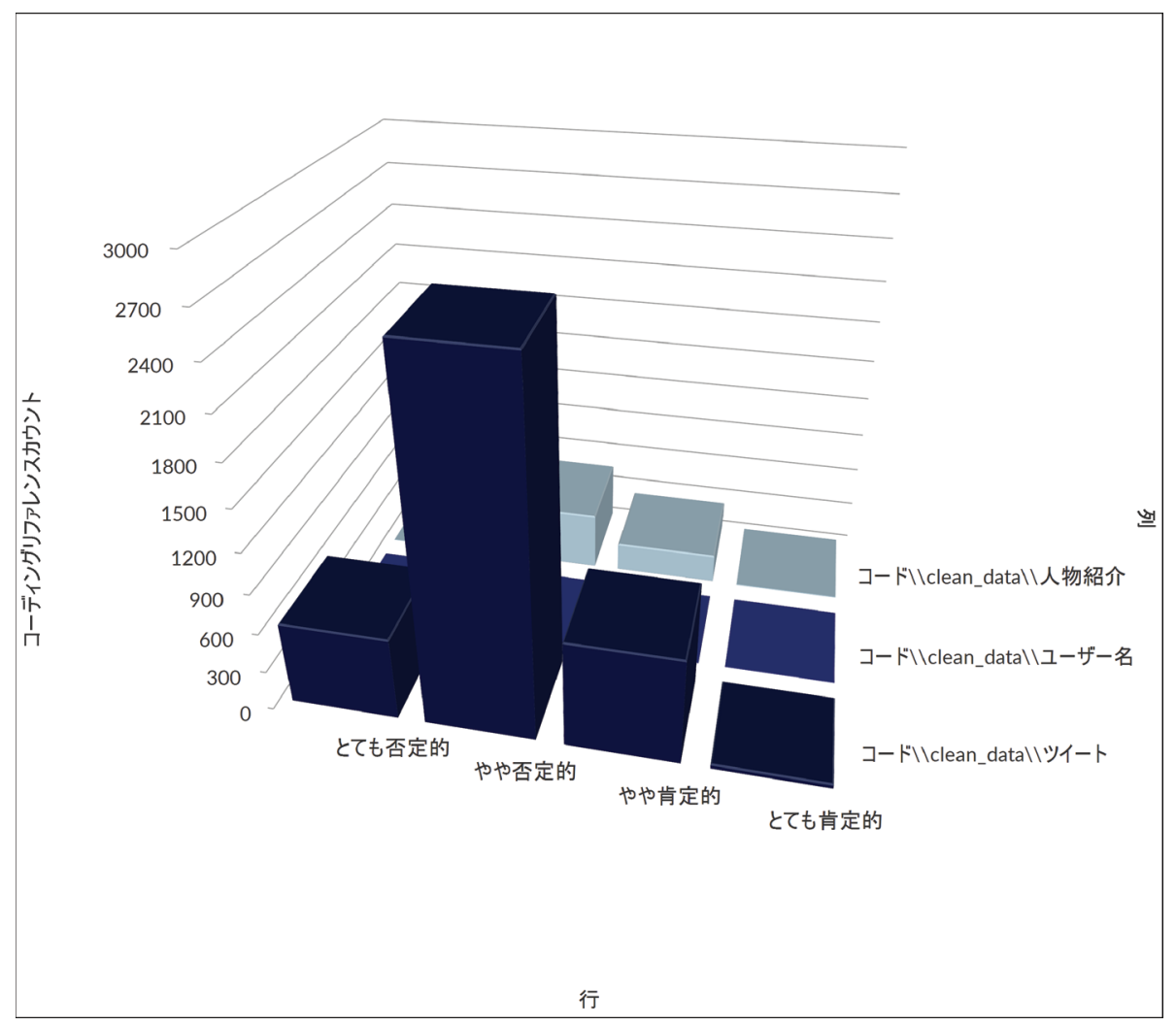

図 4. 感情の自動コーディングの結果. 


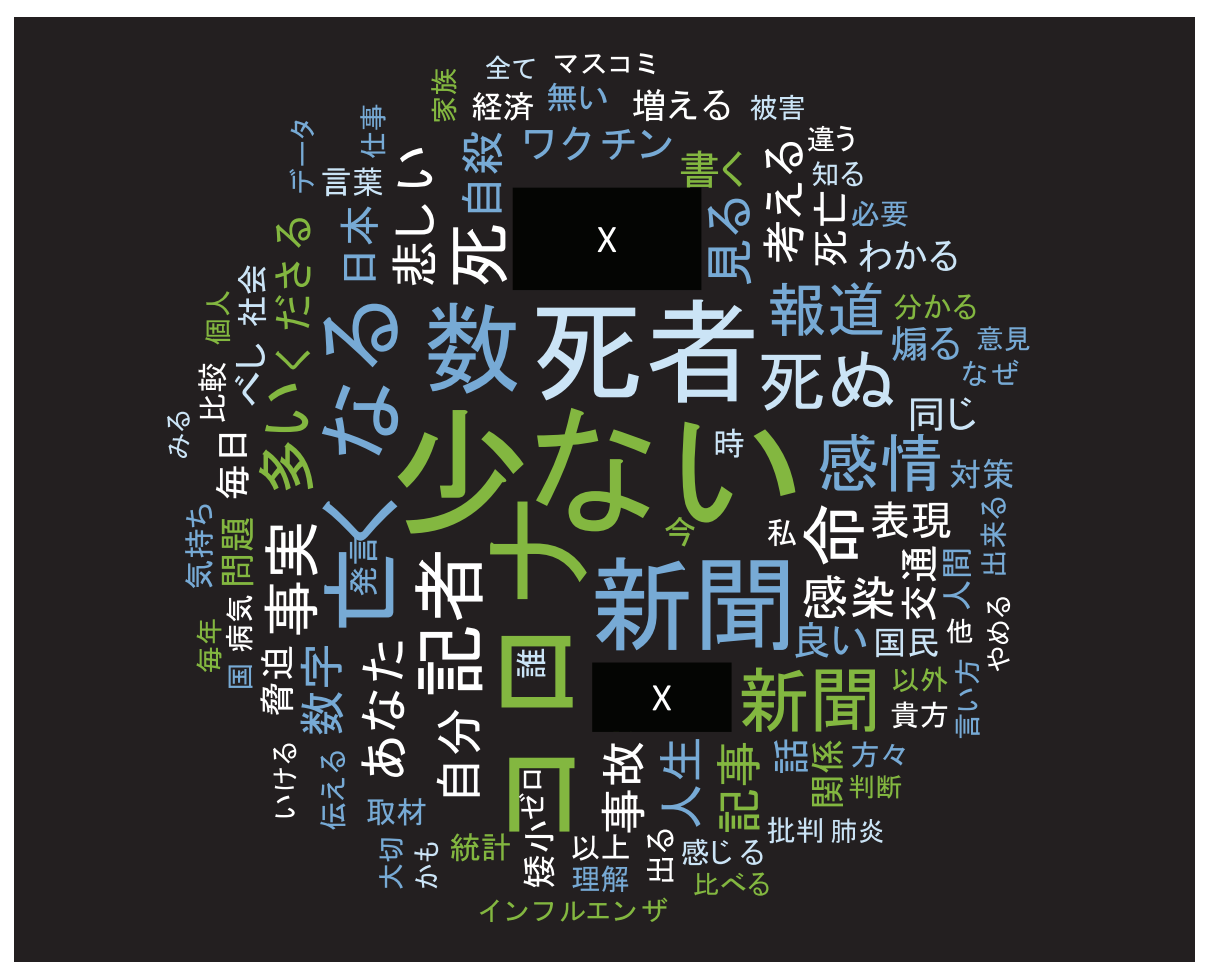

図 5.ワードクラウド (固有名詞は匿名化).

ナ感染症の) 他にも重要な事柄がある」という内容のものであった (170 件)。これらは、形式的誤謬ない し偽善の抗弁である「そっちこそどうなんだ主義 (whataboutism)」に基づくコメントである。また、71 件 の直接リプライは、元ツイートが扇動的であると見なし、批判を行っていた。

\begin{tabular}{|l|l|l|}
\hline \multicolumn{1}{|l}{\begin{tabular}{l} 
表 1. 直接リプライの内容の分類と件数. \\
\hline
\end{tabular}} & & \\
\hline 他にも重要な事柄がある & COVID-19のみ特別扱いすべきではない & 170 \\
\hline & 経済困窮による死者 & 70 \\
\hline & HPVワクチン & 49 \\
\hline & イスラエル & 10 \\
\hline 少ないという表現は妥当である & & 1 \\
\hline 扇動的である & & 216 \\
\hline 数字を「ちゃんと」報道すべき & & 71 \\
\hline 女性差別的 & & 30 \\
\hline & 感情的になるな & 150 \\
\hline & 「ポエム」だ & 124 \\
\hline 政権批判 & & 16 \\
\hline 政権擁護 & & 24 \\
\hline X社 & & 28 \\
\hline マスコミ批判 & & 186 \\
\hline 仕方ない & & 177 \\
\hline 個人攻撃 & & 39 \\
\hline
\end{tabular}


直接リプライは、元ツイートの内容ではなく、Z氏の属性に対して批判もしくは誹謗するものも多かっ た。例えば、「恥を知れ」「心の底から軽荗する」といった、元ツイートの内容には全く関係のない個人 攻撃が 195 件、X社批判が 186 件、マスコミ批判が 177 件、「感情的になるな」といった女性差別的なコ メントが150件あった。このように、Z氏がオンライン・ハラスメントを受けた理由としては、Z氏が政治 的見解を述べたこと、個人的な意見を述べたこと、女性であること、外見（ルッキズム）、という PEN アメリカの調査結果でも見られた、SNS 上で個人が意見表明を行ったこと、もしくは発言者のジェンダー やアイデンティティを理由に行われていることが分かる。これに加え、日本語インターネット空間独自の アイデンティティ攻撃の理由として、Z氏がX社の記者であるという側面があることが分かった。

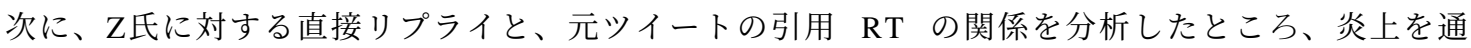
じてハラスメントを行ったユーザーは、3 つの層に分かれることが見て取れた。すなわち、1 1ンフルエ ンサー (高頻度炎上関与ユーザー群)、(2) インフルエンサーの「犬笛」に呼応する炎上加担ユーザー 群、(3)荒らしを行うユーザー群、である。

小山ら(2019) による計約 13 万人の炎上参加ユーザーの分析によれば、炎上参加者は他の炎上にも参加し やすいことが明らかになっている。5 件以上の炎上に関わったユーザー77名に関する詳細な分析において は、それらのユーザー間にはフォローハフロワー関係が密に存在し、高頻度炎上関与ユーザーは多くの フォロワー数を持ち、同じ炎上トピックに対してツイートを行うという、情報の共振構造が確認できたと いう。Z氏の炎上事件においても、多くのフォロワー数を持ち、特定の政治傾向を持つユーザーが、フォ ローハォロワー関係を結び、ユーザー間でZ氏のツイートの引用RTを順次行っていた(図 6, 図 7)。これ らユーザー群が他の炎上に関わっていたかは本稿では確認できず、高頻度炎上関与ユーザー群とみなすこ とは難しいが、多くのフォロワー数を持つユーザーの引用 RT が、フォロワーを通じて広く Twitter 全般に 拡散されていったことが推測できる(図 8)。

(2のインフルエンサーの「犬笛」に呼応するユーザー群であるが、犬笛とは「加害的もしくは有害な意味 を持つ二重、もしくはコード化された言葉や記号を使い、インターネット上の加害者グループに特定の標 的を攻撃するように合図する行為」を意味する (PEN America, n.d.-a)。先のインフルエンサーのうち、約 350 万ユーザーをフォロワーに持つH氏は、Z氏のツイートを2度に渡って引用 RT を行っている。第一回 目の引用 RT は、2021 年 8 月 4 日午後 6 時 9 分に行われ、記者は新型コロナウイルスによる死者数は多い と読者の恐怖を煽ることで販売部数を稼ぐ最低のビジネスをしている、もっと科学を勉強して冷静かつ論 理的に記事を書いてほしいが、無理であろうから当該メディア自体なくなってほしい、という内容であっ た。第二回目の引用 RT は、同日午後 7 時 11 分に行われ、 $\mathrm{Z}$ 氏によるツイートは新型コロナウイルスに 対する恐怖を煽って儲けることを正当化しており、最低である、という内容であった。

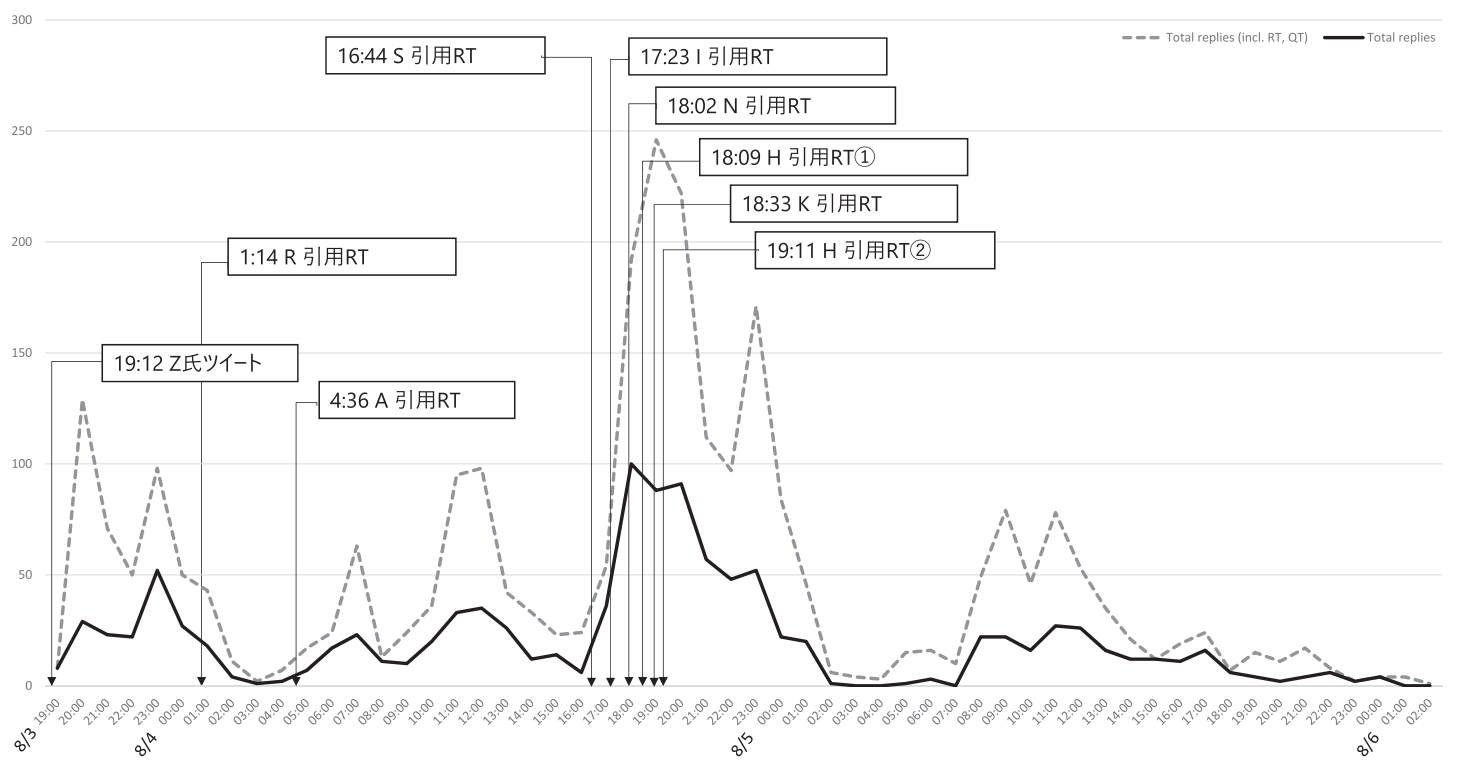

図 6.一時間あたり直接リプライとインフルエンサーの引用 RT. 


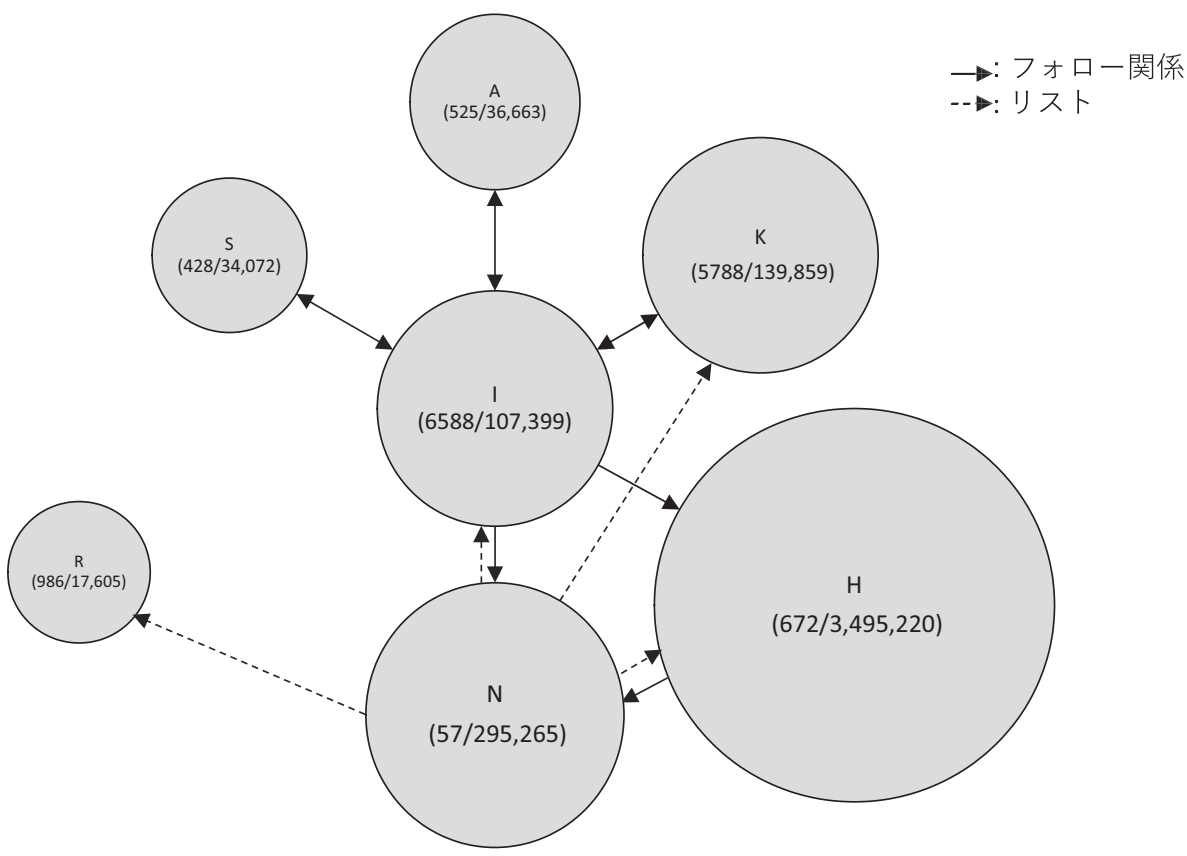

図 7. インフルエンサーのフォロー/フォロワー関係 (カッコ内フォロー数、フォロワー数).

図 8. インフルエンサーによる引用RT拡散ネットワーク図.

この 2 つのツイートに共通する主張が「煽るな」というものである。先述のとおり、直接リプライのう ち、元ツイートが扇動的であると批判したものは71件であったが、これらの発生した時間帯を時系列で確 認すると、それまでは合計 6 件しかこの内容の直接リプライがなかったものの、 $\mathrm{H}$ 氏が一度目の引用 $\mathrm{RT}$ 
をした午後6時台は7件、二度目の引用 RT を行った午後7時台は 15 件、午後8時台は 11 件と、急増してい る(図 9)。また、H氏のツイートを見て来たと述ベたツイートも3件あり、インフルエンサーの犬笛 に呼応して、わざわざZ氏のアカウントに対して直接、故意の攻撃を行っていることが見て取れた。な お、山口 $(2015,2016,2020)$ による炎上現象の既存研究によれば、炎上加担の理由として正義感をあげる 人が大半とあるが、本ユーザー群はこうした大多数の炎上加担者であることが推測される。

直接リプライの分析からは、インフルエンサー、及びインフルエンサーの呼びかけに直接・間接的に反応 したと推測されるユーザーとは別に、3荒らし（扇情的なコメントやへイトスピーチを繰り返し投稿する こと)を行うユーザー群が見て取れた。まず、195 件の個人攻撃のツイートのうち、1 2 名のユーザーが 2 度以上、繰り返し個人攻撃のリプライをZ氏に送っていた。また、図 10、図 11 は批判的な内容の直接リ プライ、及び個人攻撃のリプライの一時間あたりの数をグラフ化したものであるが、両者の数量は必ずし も呼応していない。特に一時間あたりの個人攻撃コメントが多かった時間帯 (2021 年 8 月 4 日午前 11 時 $\sim 8$ 月 5 日午前 2 時)について、先のインフルエンサーの犬笛に呼応した批判的ツイートの一時間あた り数と比較すると、特に増減傾向に類似性が見られない(図 12)。これらから推測されるのは、常日頃か ら Z 氏の発言をモニターし、期を見て荒らしを行うユーザー群が存在する可能性である。実際、自称メ ディアウォッチャーで7千余のフォロワーを持つユーザーが、2021 年 3 月 18 日に、X社には一部、低質 かつイデオロギー色の強い記者がいる、という内容のツイートを行い、 $\mathrm{X}$ 社の「低品質」記者一覧とし て、 Z 氏ほか複数名の X 社に関係する記者の Twitter アカウント情報を掲載している。なお、こうしたユ 一ザーが、 Z 氏の他のツイートに対しても繰り返し荒らしを行っているか、またいかなる動機に基づいて 荒らしを行っている・行ったのかはさらなる調査分析が必要である。

\section{オンライン・ハラスメント対策}

国内外の既存研究から、誰であってもオンライン・ハラスメントを受ける可能性があること、一方で八ラ スメントを受けやすい属性があること、ハラスメントの被害は身体的・精神的に甚大であることが明 らかとなった。また、日本語環境の Twitterにおける事例として、X社の記者ツイート「炎上」事件を分析 し、オンライン・ハラスメントを行うユーザーにはインフルエンサー群、インフルエンサーの犬笛に呼応 する炎上加担ユーザー群、荒らしを行うユーザー群の三層があり、それぞれがなる形で一人のユーザー に対してハラスメントを行っていたことが見て取れた。このようなオンライン・ハラスメントに対して、 ユーザーはどのような対策を取ることができるのだろうか。

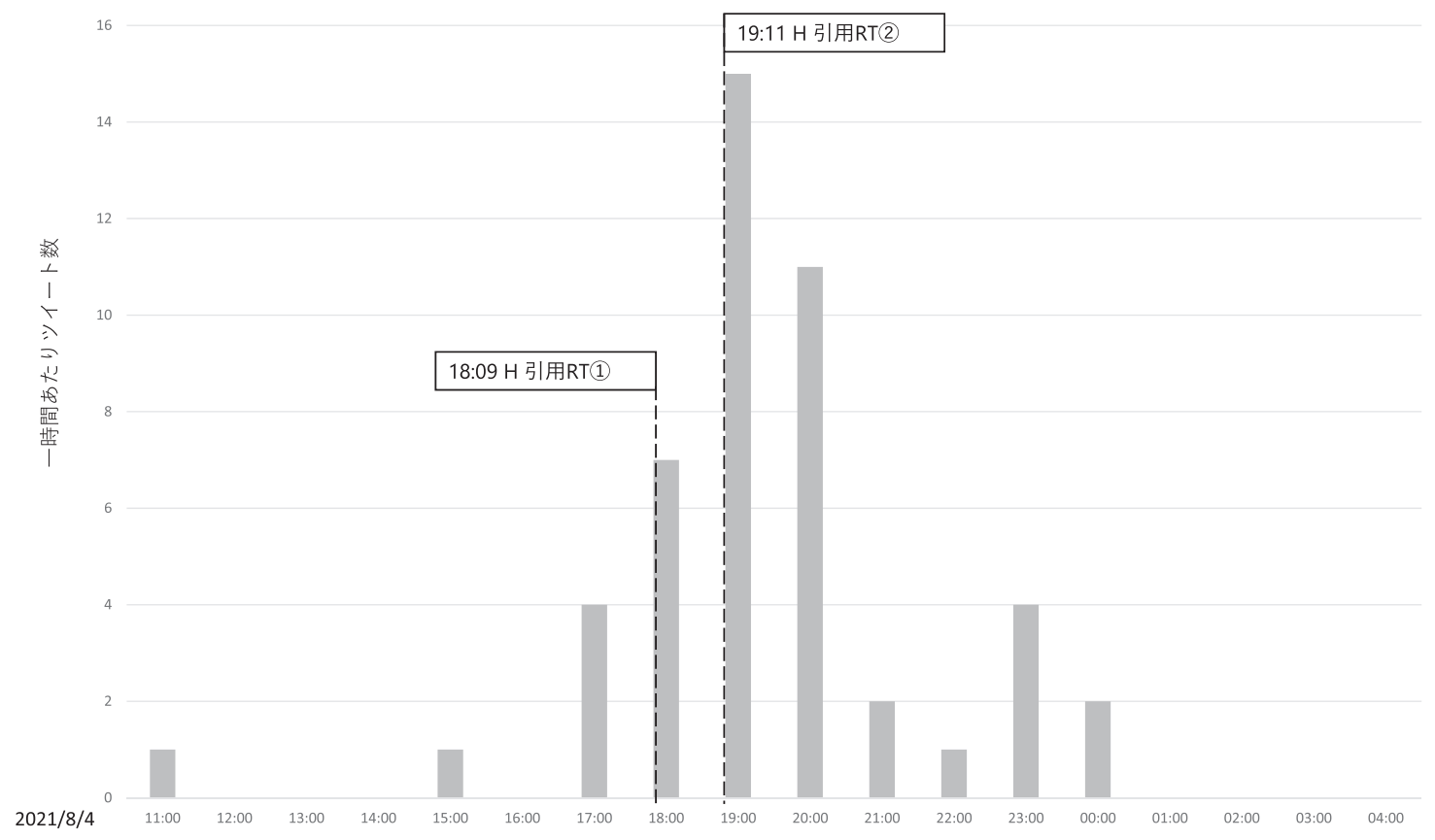

図 9.「煽るな」という内容の一時間あたり直接リプライおよびインフルエンサーの引用リツイート時間. 


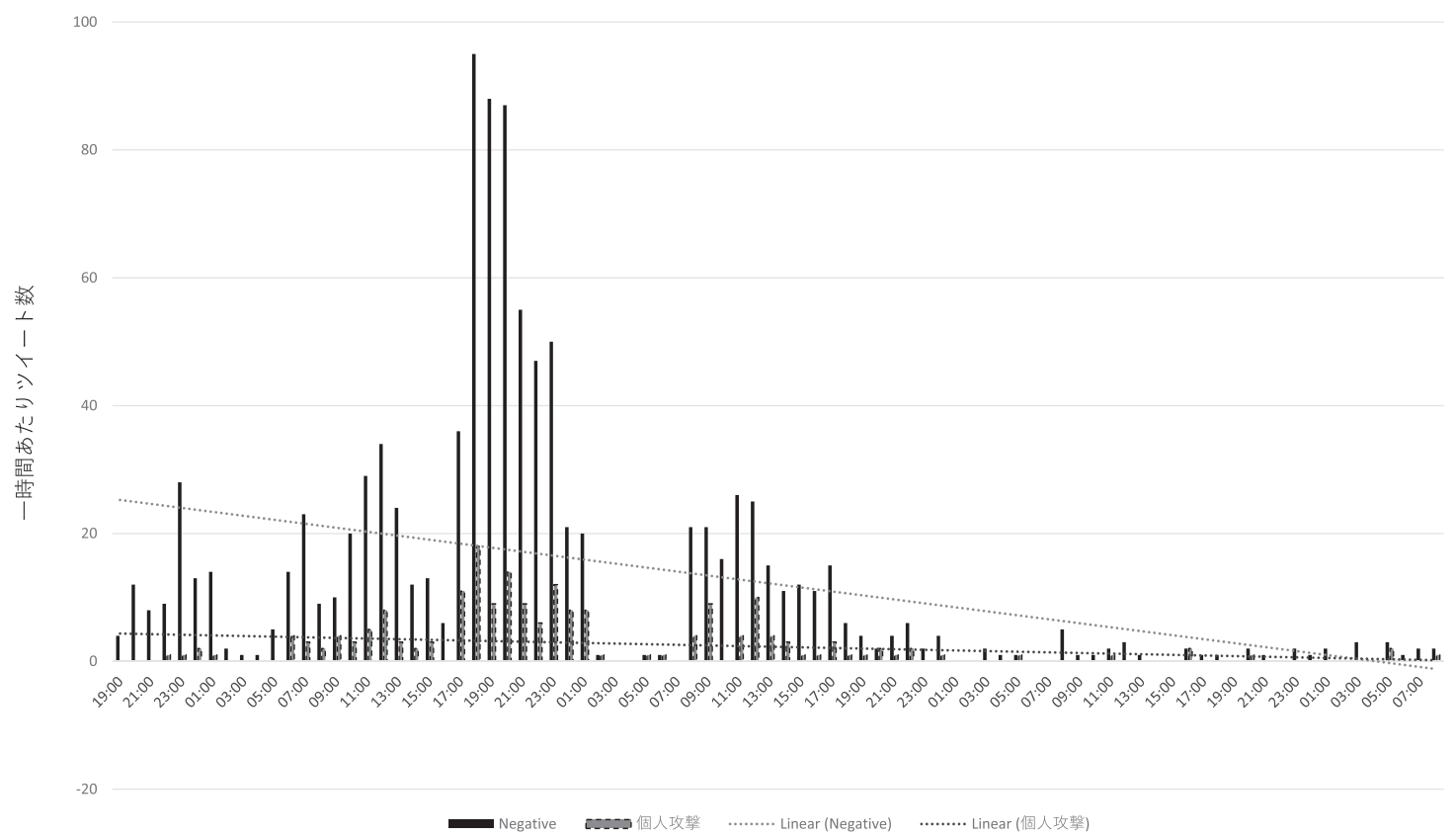

図 10.一時間あたり批判的コメントと個人攻撃コメント.

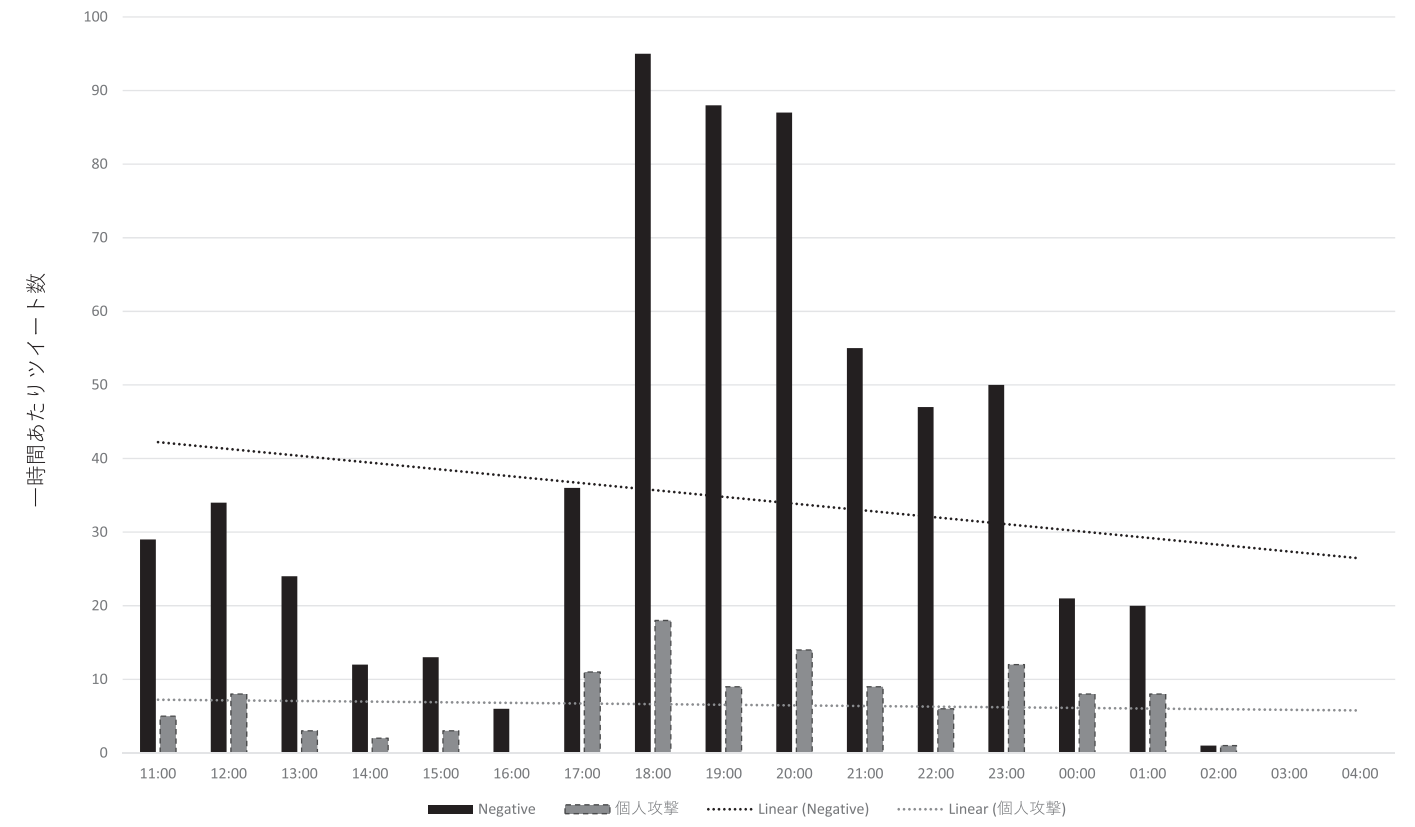

2021/09/06

図 11. 一時間あたり批判的コメントと個人攻撃コメント.

各国の女性議員へのオンライン・ハラスメントの調査分析を行ったヤンコビッチら (2021) は、報告書に 政策提言を記載している。具体的には、SNS プラットフォーム企業への提言として、

・ 個別ツイートの通報ではなく、インシデント報告制度の導入

・プラットフォームから各企業・団体の SNS 担当者への情報共有 


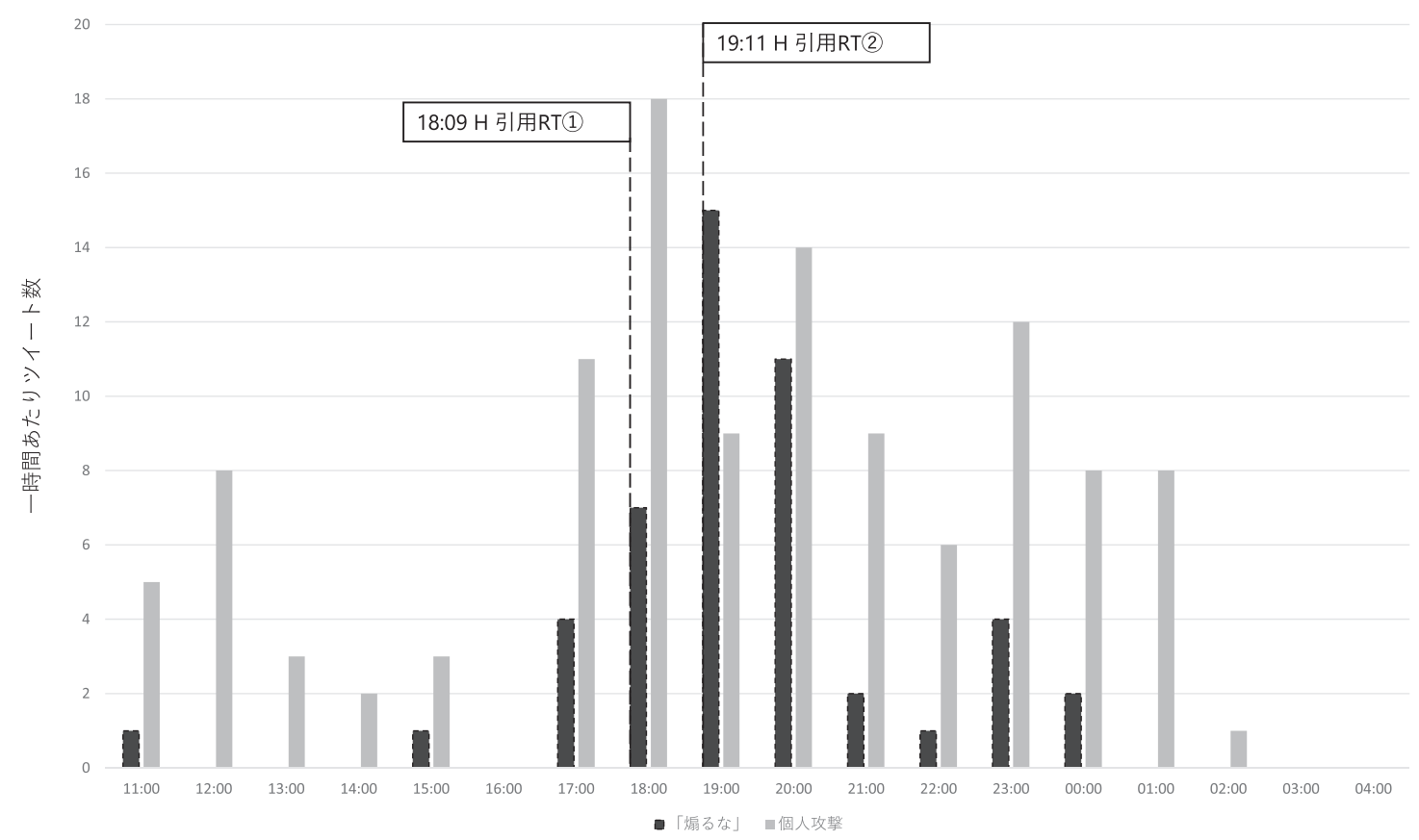

2021/09/06

図 12.「煽るな」コメントと個人攻撃コメントの比較.

- 利用規約の適用の徹底

・ ナッジ機能の強化

・プラットフォーム間のオンライン・ハラスメント防止機構の設置

政策担当者への提言として、

・ SNS 規制の強化（透明性のある報告システム、プラットフォームの報告義務）

・ディープフェイクなどに加え、ジェンダー化されたハラスメントも規制対象に含めるべき

・ 米国で1994年に制定された「女性に対する暴力阻止法案」に、物理的な危害だけでなくオンライ ン上の危害も含めるべき (Congress.gov, 1994)

雇用者への提言として、

・ 被雇用者の SNS 発信に関するガイドラインの設定

- 心理的・道徳的・金銭的な支援。オンライン・ハラスメント被害者の晒し防止対策のためのサー ビス料の支払い、プラットフォームへの被害報告代行

を挙げている。しかし、日本語のインターネット環境の場合、オンライン・ハラスメントに関する社会的 認知度が低い上に、主に外国に本社を置くプラットフォーム企業の対策も十分とはいえないため、ハラス メント防止策はユーザー個人、もしくは個人が所属する組織が取ることが求められているのが現状であ る。以下、日本語SNS環境の特殊性を念頭に置きつつ、個人および組織がとり得るオンライン・ハラスメ ント対策について、Twitter を中心に述べる。 
表 2. ハラスメント対応ログ.

\begin{tabular}{|c|c|c|c|}
\hline 日付 & 時間 & 詳細 & 結果・何をすべきか \\
\hline & & & \\
\hline & & & \\
\hline & & & \\
\hline & & & \\
\hline & & & \\
\hline & & & \\
\hline
\end{tabular}

オンライン・ハラスメント対策 (個人)

ハラスメント対策の最も基本的な行動としては、ミュート（特定のアカウントのツイートがタイムライン に表示されないようにする Twitter の機能)、ブロック (特定のアカウントによるメッセージの送付、ッイー トの閲覧、フォローの禁止)、通報（攻撃的なツイートまたはアカウントを Twitter 運営に報告すること） の3つがある (PEN America, n.d.-d). また、いつどこでどのようなハラスメント被害を受けたのか、ログを 取っておくことも重要である。こうした情報は、オンライン・ハラスメント行為を警察や弁護士に相談す る際、重要な証拠となる (表 2)。

また最近では、オンライン・ハラスメント対策の専用ツールが開発されており、こうしたツールの導入も 間接的なハラスメント防止になり得る。例えば Block Party というツールは、誰からの返信が見たいか、 見たくないかをフィルターとして設定することで、基準に該当する返信を全て自動でミュートする。これ により、ユーザー自身は Twitter を開いてすぐに嫌がらせのツイートを目にするというようなことを経験 せずとも、自分自身で後日、もしくは信頼できる人物に依頼して返信の内容を確認することが可能になる (Cho, n.d.)。さらに、Twitter 社が、「安全モード」機能を検討中である旨が発表された (Doherty, 2021)。 本機能を有効にすると、自分に対して有害な言葉を使ったユーザーや、荒らしを行ったユーザーが自動的 に7日間ブロックされるという。その他、全般的なデジタル衛生のチェックや、SNSアカウントのチーム 運用も対策として考えられる (Jankowicz et al., 2021)。

オンライン・ハラスメント対策 (組織)

昨今は、議員、記者、研究者など既存メディアを通じて従来発信してきた者でなくても、SNS を通じて 発信し、広く社会にアウトリーチすることが求められている。またZ氏の例では、 Z 氏がX社に所属する ことを理由にハラスメントが行われていた。炎上やオンライン・ハラスメントは個人アカウントのみなら ず、大小様々な組織に対しても発生している(榊・鳥海, 2020)。したがって、所属員の SNS アカウント運 用とそれに伴うハラスメント被害について、組織が全く関与しないことは難しい。

組織ができる対策として、まずは炎上決着メカニズムを理解することが不可欠である。田代・折田 (2012) は、ネット炎上を「不具合」に対して決着をつけようとすること、と見なし、炎上が収束するため には「決着」が必要とした。そして、ハラスメントが収束するためには攻撃側が納得することが必要であ り、法的に問題があれば法的に処理されることで収束に向かう（図 13)。謝罪を行ったとしても、単に謝 罪しただけでは収束せず、謝罪が受け入れられて収束する。炎上が議論へ繋がって収束する、コメント欄 やブログそのものの削除 (Twitter の場合はリプライ機能の制限や Twitter アカウントの削除)、炎上を無視 し、忘れ去られることで収束を迎えることもある、とする。所属員の SNS アカウントが万が一炎上した り、ハラスメントの被害者となった場合、そうした行為を受けたことを批判したり懲罰の対象とするので はなく、収束には様々なパターンがあることを理解することが、SNS 運用者支援の第一歩であろう。

第二に、組織がインターネット上でどのような属性を与えられているか、それに基づく荒らしユーザーの 確認が求められる。事例分析ではメディア企業である X 社の例を扱ったが、他にも例えば大手消費財化 学メーカーである花王は、韓流ドラマをよく流すフジテレビへのスポンサーを多くつとめていたことか ら、「韓国に貢献し日本文化を破壊する企業である」という䛊情報が拡散し、インターネット上で批判を 受けた（田代・折田, 2012）。先述のとおり、オンライン・ハラスメントには加害者の標的になりやすい属 性の集合があり、集合の共通部分においては最もハラスメントに遭う確率が高くなる。企業が自社のブラ ンド認知度を調査するのと同様、ハラスメントの標的となる可能性についても検討する必要がある だろう。 


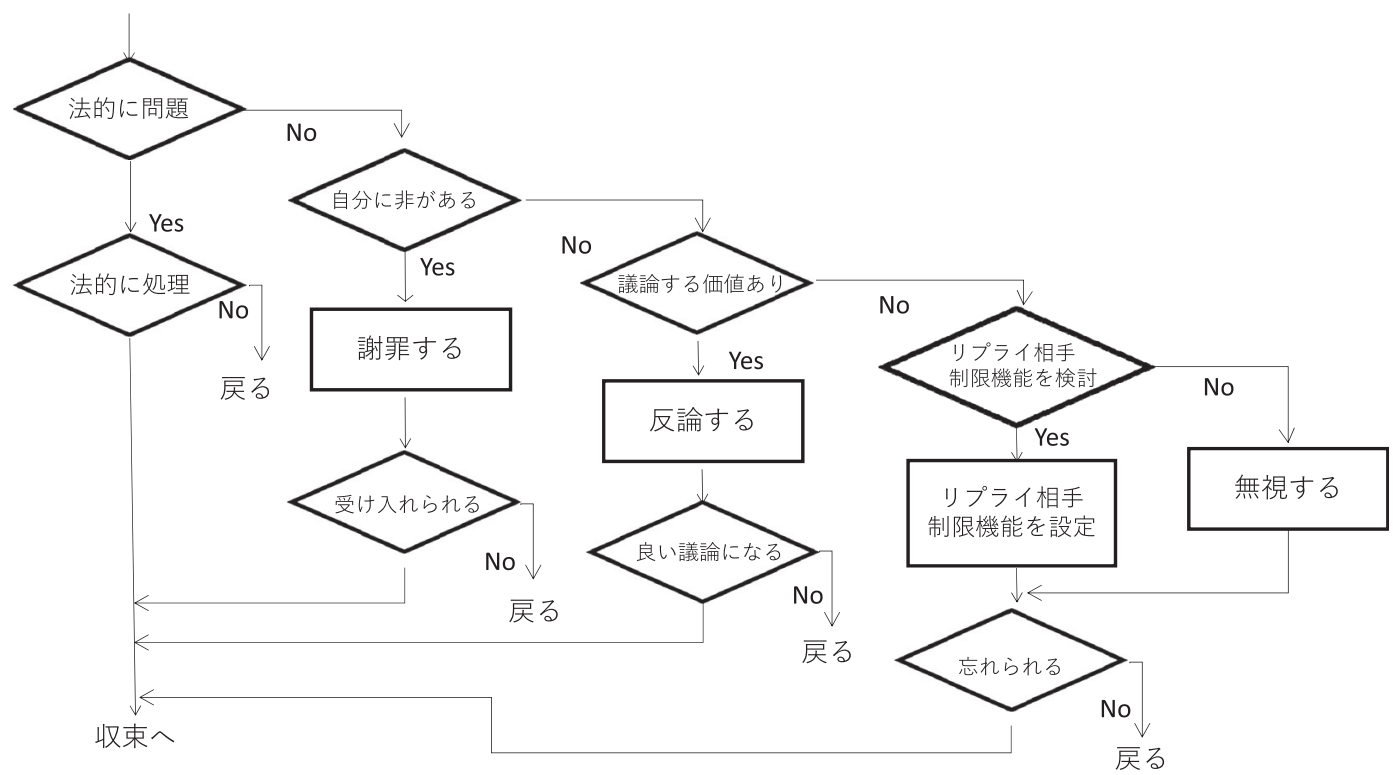

図 13. 決着のフロー (Twitter を想定、田代・折田 2012) に基づく．

先に、個人ではミュート、ブロック、通報が最も基本的かつ効果的なハラスメント対策であると述べた。 他方で、議員、記者、公的組織の所属員によるアカウントなど、発信する情報に公共性があると見なされ る場合、ブロック行為が好ましくないと見なされるケースもある(日本経済新聞, 2021)。したがって、組 織内でブロック機能の利活用について議論の上、ガイドラインを設け、適切に運用することが求められ る。仮に所属員が自己防衛としてとり得る有効策を、所属組織が禁じるようであれば、所属員がハラスメ ントを受け身体的・精神的ダメージを受ける可能性も高まるのであるから、より充実した心理的・道徳 的・金銭的な支援が必要となる。

日本では、2021 年 4 月 21 日、インターネット上で誹謗中傷の投稿を行った人を特定しやすくするためのプ ロバイダー責任制限法の改正案が可決され、加害者の特定にかかる手続きが簡素化された。また、10月 7 日には、刑法の「侮辱罪」に懲役刑を追加する法改正の要綱案が、法制審議会の部会により取りまとめら れ、法務大臣に答申するとの報道がなされている（共同通信，2021）。それでも開示手続きなど、オンライ ン・ハラスメントの直接的・間接的費用の負担は加害者よりも被害者にとって重いことは変わらない。し たがって、例えば、弁護士保険の費用一部負担といった形で、組織が所属員への金銭的支援を行うことを 検討すべきであろう。

\section{おわりに}

国内外の先行研究から、誰であってもオンライン・ハラスメントを受ける可能性がある一方で、ハラスメ ントを受けやすい属性があること、また、ハラスメントはオンラインで行われるものであっても、被害者 が受ける身体的・精神的ダメージは看過できないことが明らかとなった。日本語環境の Twitter における オンライン・ハラスメントの事例として、大手メディア企業X社の記者ツイート「炎上」事件を分析した 結果、ハラスメントを行うユーザーにはインフルエンサー群、インフルエンサーの犬笛に呼応する炎上加 担ユーザー群、荒らしを行うユーザー群の三層があること、さらに、それぞれが異なる形で一人のユーザ 一に対してハラスメントを行っていたことが観察できた。事例分析は炎上事例の一例でしかないため、一 般化は難しいが、SNS 上の炎上現象に関する先行研究の結論を補完するものである。本稿で導出した仮 定に基づき、より大規模な分析を行うことを将来の課題としたい。

本稿の最後には、日本語のインターネット環境の場合、オンライン・ハラスメントに関する社会的認 知度が低いことや、Twitter など外国に本社を置くプラットフォーム企業に対策を求めることの難しさを鑑 み、SNS ユーザー個人、もしくは個人が所属する組織が取るべきハラスメント防止策を詳述した。日本語 環境の SNS については、オンライン・ハラスメントという概念自体が知られていない状況であり、その社 会的影響に比して、ハラスメントにあった被害者を中心に検討した論考が少ない。こうした意味で、本稿 
が学術的な議論の広がりと深化の一助となり、実効的なハラスメント防止策に繋がることを期待したい。

データ利用可能性

本論文の研究結果の基礎となるデータは，すべて本論文中に示されており，追加のソースデータは必要と されていない。例外として、ソーシャルメディアのデータには倫理上および著作権上の制限があるため、 本研究の基礎データを共有することはできない。対象となるデータは、2021 年 8 月 3 日に投稿された大 手メディア企業に所属する女性記者 (以下Z氏) のツイートと 2021 年 8 月 3 日 7 日の間に Z 氏アカウント に直接届いた 2,817 件の直接リプライ (直接リプライ 1,175 件、これらのリッイート 1,499 件、引用リッイー ト143 件)、及び 5,595 件の本リツイートの引用リツイートである。本研究の再現を可能にする詳細な情報 は、「事例分析」部分に記載されている。方法に関する質問がある場合は、著者(tonami.aki.ka@u.tsukuba.ac.jp) に連絡されたい。

Tweet ID についても、Z 氏の匿名性を守るためのセキュリティ上の配慮から共有しない。同分野の研究者 が、善意と明確な研究目的をもってIDの閲覧を希望する場合、データの利用目的と方法を明記の上、著 者 (tonami.aki.ka@u.tsukuba.ac.jp) に連絡されたい。

謝辞

本稿の執筆にあたり、M氏には荒らしユーザーや個人でできるオンライン・ハラスメント対策について助 言をいただいた。心から感謝申し上げます。

\section{参考文献}

Berry E: Online violence just as destructive as offline violence. 2019 (accessed 24 September 2021).

Reference Source

BIGLOBE 株式会社: SNS での誹謗中傷に対する罰則「強化すべき」8 割強 BIGLOBE が「with コロナ時代のストレスに関する調査」第2弾を発表 〜 with コロナ時代に行動をSNSに投稿することに抵抗「感じる」3割強 。 2020. (accessed 13 September 2021).

Reference Source

Cho T: Block Party の日本語使い方ガイドが出来ました!. n.d. (accessed

13 September 2021).

Reference Source

Congress.gov: H.R.3355 - Violent Crime Control and Law Enforcement Act of 1994. 1994. (accessed 20 October 2021).

Reference Source

Doherty J: Introducing Safety Mode. 2021. (accessed 13 September 2021). Reference Source

Fung A, Gilman HR, Shkabatur J: Six Models for the Internet + Politics. International Studies Review. 2013; 15(1): 30-47.

Publisher Full Text.

Gosse C, Veletsianos G, Hodson J, et al.: The hidden costs of connectivity: nature and effects of scholars' online harassment. Learning Media and Technology. 2021; 46(3): 264-280.

Publisher Full Text.

Inter-Parliamentary Union: Sexism, harassment and violence against women in parliaments in Europe. Inter-Parliamentary Union; 2018.

Reference Source

Jankowicz N, Hunchak J, Pavluic A, et al.: Malign Creativity: How gender, sex and lies are weaponized against women onilne. Washington D.C.: Wilson Center; 2021.

Reference Source

Lee E: Into 2020: The State of Online Harassment and Opportunities for Collaboration. Online SOS. 2019.

Reference Source

McCay-Peet $L$, Quan-Haase A: What is social media and what questions can social media research help us answer?. Sloan L, Quan-Haase A, editors. The SAGE Handbook of Social Media Research Methods. London: SAGE; 2017. PEN America: Dog Whistling. N.d.-a. (accessed 13 September 2021a). Reference Source

PEN America: Online Harassment Survey: Key Findings. N.d.-b. (accessed 7 September 2021b).

Reference Source
PEN America: Online Harassment. N.d.-c. (accessed 7 September 2021c). Reference Source

PEN America: Respond. N.d.-d. (accessed 13 September 2021d). Reference Source

Sobieraj S: Credible Threat: Attacks Against Women Online and the Future of Democracy. Oxford: Oxford University Press; 2020.

Statista Research Department: Leading countries based on number of Twitter users as of July 2021. (accessed 7 October 2021).

Reference Source

Vogels EA: The State of Online Harassment. Pew Research Center; 13 January 2021.

Reference Source

共同通信:「侮辱罪に懲役刑」厳罰化答申へ. 2021. (accessed 7 October 2021).

Reference Source

榊剛史，鳥海 不二夫:ソーシャルポルノ仮説に基づくメディア企業SNSアカ

ウントの扇動性に関する分析. The 34th Annual Conference of the Japanese

Society for Artificial Intelligence. 2020

三省堂: スーパー大辞林. 2013.

申 琪榮，濱田 真里: 女性議員に対するオンラインハラスメントー首都圈の女 性地方議員の事例を手がかりに一. 生活経済政策. 2021; 291: 19-23.

田代 光輝，折田 明子: ネット炎上の発生過程と収束過程に関する一考 察〜不具合に対する嫌がらせと決着による収束〜. 情報処理学会研究報告. 2012.

日本経済新聞: 東京都、新たに5386人感染 過去2番目の多さ 7日平均で前週 の117.9\%. 2021. (accessed 20 October 2021).

Reference Source

プラン・インターナショナル: 若年女性ヘのジェンダーを理由にしたオンラ イン・ハラスメントに関する調査結果 日本の調査報告書. 2020 October. Reference Source

森下 真理子: 自宅でのモバイルネット利用が増加!コロナ禍が浮き彫りにし た情報メディアニーズ. 2021. (accessed 22 September 2021).

Reference Source

山口 真一: 実証分析による炎上の実態と炎上加担者属性の検証. 情報通信学 会誌. 2015; 33(2): 53-65.

Publisher Full Text

山口 真一: 炎上加担動機の実証分析. 2016 年社会情報学会(SSI) 学会大会.

2016.

Reference Source

山口 真一: 正義を振りかざす「極端な人」の正体. 光文社; 2020. 


\section{Open Peer Review}

\section{Current Peer Review Status:}

\section{Version 1}

Reviewer Report 20 December 2021

https://doi.org/10.5256/f1000research.78433.r100521

(C) 2021 Yamaguchi S. This is an open access peer review report distributed under the terms of the Creative Commons Attribution License, which permits unrestricted use, distribution, and reproduction in any medium, provided the original work is properly cited.

\section{Shinichi Yamaguchi}

Center for Global Communications, International University of Japan, Niigata, Japan

本研究では、オンライン・ハラスメントという概念を導入し、その概要を明らかにすると共に、Twitter で発生した炎上事例を分析してハラスメントを行うユーザを整理しています。また、最後には個人と組 織がとるべき対策について詳細に述べられています。著者らが指摘するように、炎上の被害に遭った当 事者視点に基づいて分析した研究は少なく、そこにオンライン・ハラスメントという概念を導入して整 理・分析を行ったことは意義が高いといえます。実証分析も丁寧で、社会の関心も高い分野といえ、研 究成果に関心のある読者も多いでしょう。

しかしながら、これを学術論文として考えた時に、いくつか問題点を抱えていると思います。具体的に は、以下の点に改善出来るところがあると思います。

\section{(1)既存研究レビュー・分析・対策の関連性がない}

最も大きいのが、各節の関連性がなく、報告書のように知見を羅列しているところだと思います（各知 見自体は非常に有意義なものですが、学術論文としては課題があるという意味です）。例えば、大きく 紙幅を割いている図2について、「悪意をもつ行為者が、様々な方策を使用し、多数の媒体を通じて、 複数の場所で、標的（被害者）に危害を与えるメカニズムが存在する」と指摘している一方で、分析さ れているのはTwitterのみです。さらに、結構な分量を割いている「オンライン・ハラスメント対策」も 実証分析と全く関係のない記述が延々と続いています。せっかくハラスメントユーザのパターンを明ら かにしたのに、活かされていません。

その要因の1つに、節の構成があると思います。まず、序盤では「はじめに」と「オンライン・ハラス メントの現状」とあります。後者は既存研究レビューといえますが、本当に現状を述べるのが中心とな っており、既存研究にはどのような課題があり、そのために本研究では〜を明らかにするという明確な 研究の問いが示されていません。強いて言うなら「欧米の言語環境の研究しかないので日本語環境での 一例を記述する」というところがそれに該当すると思いますが、もう少し本研究の新規性・社会的意義 を示すためにも、既存研究との位置づけとResearch Questionをはっきりさせた方が良いと思います。 そのためには、既存研究よりも、本実証分析の内容に関連するものが必要だと思います。具体的にいう と、オンライン・ハラスメントの攻撃者を分析した研究です。Research gapやResearch Questionにつ いて、別途節を設けても良いかもしれません。

また、事例分析の節では手法と分析結果が一緒の節に入っているので、分けて書くと同時に、手法をも つと詳しく書いたほうが良いと思います。特に、本研究で重要な知見である3つの層の分類について、

「元ツイートの引用RTの関係を分析」としか書かれておらず、手法が分かりませんでした。 
そして、得られた結果と先行研究との関係を議論する節や、結果から導かれる対策を論じる結論節を用 意したほうが良いと思います。現在の「オンライン・ハラスメント対策」で書かれている内容は興味深 いのですが、これらは縮小させ、分析から得られる対策の検討に紙幅を割くことを推奨します。

(2)事例が1つしかない

1事例をもとにオンライン・ハラスメントのパターン分析をするのは、やや無理があるように思いまし た。事例分析なので数は多くなくて良いと思いますが、頑健性を検証するためにももう2, 3事例の分析 があった方が良いと思います。ただし、これは難しいと思うので、修正要求ではなく修正提案となりま す。

(3)その他 (細かい点)

・分析において、「「感情的になるな」といった女性差別的なコメント」とありますが、「感情的にな るな」単体で女性差別的と解釈してよいのか疑問が残りました。女性差別的に使われることが多いのは 理解していますが、男性相手にも使う言葉だからです。また、「心の底から軽藿する」が個人攻撃に入 るのならば、「感情的になるな」も個人攻撃なようにも思います。

・小山（2019）が文献リストに見つかりませんでした。

\section{本研究は明確かつ正確に提示されたものであり、最新の文献を引用していますか。} はい

研究設計は適切で学術的価値がありますか。

一部該当

方法と分析について第三者による再現が可能となるよう十分な詳細が提示されていますか。 一部該当

（該当する場合は要回答）統計分析および解釈は適切ですか。 一部該当

結果の基礎となるソースデータはすべて入手可能で再現性を十全に保証していますか。 ソースデータは不要

結論は結果により妥当な裏付けを得ていますか。 一部該当

Competing Interests: No competing interests were disclosed.

Reviewer Expertise: 計量経済学, ソーシャルメディア, 社会情報学, 情報経済論

I confirm that I have read this submission and believe that I have an appropriate level of expertise to confirm that it is of an acceptable scientific standard, however I have significant reservations, as outlined above.

Author Response 13 Jan 2022

Aki Tonami

山口先生 
査読コメントをいただき、誠にありがとうございます。

(1)既存研究レビュー・分析・対策の関連性がない

本ジャーナルの研究論文の前提として「Research Articles should present originality in findings and insights and offer theoretical, empirical, experimental and/or methodological advances to their respective fields of research. Null and negative findings and reanalyses of previous studies leading to new results, as well as confirmatory results, are also encouraged.」とあります (

https://f1000research.com/for-authors/article-guidelines）。研究の独自性を提示する に際し、どの程度先行研究のレビューに紙幅を割くべきかは分野によって異なりますが、 本稿ではあえて、オンラインハラスメントが言語、文化、文脈に高度に依存することから 、主に英語による、英語圏におけるオンラインハラスメントに関する先行研究の網羅的レ ビューを避け、そもそも存在していない日本語環境におけるオンラインハラスメントの論 考の第一号となることを目指しました。したがって、Research gapは既存研究がないこ と、となります。また本稿は質的研究であり、実証や仮説検証を目的とするものではあり ません。よって、Research questionは「オンライン・ハラスメントの現状はどうなって いるか」という記述的問いになります。ただしこれが分かりにくいとのご指摘かと存じま すので、その旨加筆修正いたしました。

なお、本論文が発表された後に発表されたオンラインハラスメントに関する日本語の研究 では、例えば、法学セミナー2021年12月号特集『言論に対するゆるしと制裁』が参考に なるかと考えます。

「学術論文としては課題がある」とのご指摘については、想定されている学術論文が具体 的にどのような論文なのか不明なため、前提と求められている条件を明示していただけれ ば幸いです。（例えばIMRaDの形式で書かれることの多い量的研究の論文なのか、など。 )

図2において、オンラインハラスメントがTwitter以外の複数のプラットフォームに渡って 行われていると述べているのはご指摘のとおりです。しかしながら、マルチプラットフォ 一ムにおけるハラスメントについては本稿の対象範囲外ですので、今後の課題として脚注 を追加いたしました。

手法を「もっと詳しく書いたほうが良い」とのこと、「元ツイートの引用RTの関係を分析 」について詳細を記述しました。もし、その他にも不足点がある場合、何をどの程度詳細 に書けば、いずれの基準にもとづいて適切と思われるのか、ご教授いただければと思いま す。

(2)コメント「事例が1つしかない」

論文において本事例をもってのみ一般化することは難しく、SNS上の炎上現象に関する先行研究 の結論を補完するものである、と記述したとおりです。

(3)その他 (細かい点) について

第一のコメントは質的データ分析を行った際のコーディングについてのご質問かと思いま すが、「女性が感情的である」というのはジェンダー・ステレオタイプ（「女は優しい」

「男はたくましい」「女は世話好き」「男は数字ができる」のような、男女の性格や能力 、役割、行動などに関する単純で固定化された考え方（森永 2013））のひとつで（ Weigard et al. 2021）、こうした偏見が他者認知をゆがめ、性差別、なかでも善意的性差 別（benevolent sexism）に繋がることは既存研究で明らかになっています（Glick \& Fiske, 1996, 1997, 1999, Correll et al., 2020）日本語のオンライン環境においても、特に 
女性に対し「感情的である」として発話のパフォーマンスを攻撃することで、発言者の意 見を抑え込むことが指摘されています（田中, 2020）。男性も「感情的になるな」と批判 を受けることがあるとのご指摘ですが、これは「感情的になること」一一前述のとおり、 一般的に女性の性格や能力、役割、行動に紐付けられているステレオタイプですが一一が 誤っている、よくない点であると捉えられているため、指摘しあげつらわれていると考え られます。こうした理由から、「感情的である」というのは個人攻撃ではなく、女性差別 的、すなわち対象者が属する（とみなされている）集団に対する差別的発言であると判断 しました。

他方、個人攻撃については、対象者が属する集団（この場合、女性という性グループや、 メディア企業）ではなく、記者本人に対する攻撃をこのカテゴリーに分類しました。著作 権とプライバシーの保護に留意しつつ、それと分かりやすい例を追加いたしました。 なおコーディングについては、本稿ではデータを読みながら探索的に自由にコードを付す

「生成的コーディング generative coding」を行いました。質的研究で採用されることの 多いこのコーディングでは、解釈が重要な機能を果たし、主体的なものと考えられます。 また、このため複数のコーディング作業者をおくことは稀で、この点は選定されたコード 群からコードを選んで付し、複数のコーディング作業者を置いてその間の一致度を評価す る「標準化コーディング standardized coding」とは異なることを申し添えます（大谷 2019)。

オンラインハラスメント対策に関しては、先述のとおり、本稿は質的研究であり、実証や 仮説検証を目的とするものではないこと、またResearch questionも「どうなっているか ?」という記述的問いであり、「どうすればいいか？」という「処方的問い」ではないこ とから（大谷 2019）、本稿の分析から得られた知見を対策の一助とすることは回避しま した。他方、主に英語圏の先行研究、及び「炎上」についての日本語の先行研究には対策 案として採用されるべき貴重な知見も示されており、それらを日本語のインターネット環 境や、個人・個人が所属する組織の実務的な観点から検討し、有用と思われるものを提言 いたしました。こうした背景が分かりにくいことはご指摘のとおりと考えますので、加筆 修正いたしました。

小山ら（2019）の論文の文献リスト漏れについてご指摘ありがとうございました。その他 参考文献 の追加論文とともに挿入しました。

Correll SJ, Weisshaar KR, Wynn AT, et al.: Inside the Black Box of Organizational Life: The Gendered Language of Performance Assessment. Am. Sociol. Rev. 2020; 85(6): 1022-1050. https://doi.org/10.1177/0003122420962080

Glick P, Fiske ST: The Ambivalent Sexism Inventory: Differentiating Hostile and Benevolent Sexism. J. Pers. Soc. Psychol. 1996; 70: 491-512. https://doi.org/10.1037/0022-3514.70.3.491

Glick P, Fiske ST: Hostile and Benevolent Sexism. Psychol. Women Q. 1997;

21(1): 119-135. https://doi.org/10.1111/j.1471-6402.1997.tb00104.x

Glick P, Fiske ST: The Ambivalence toward Men Inventory: Differentiating hostile and benevolent beliefs about men. Psychol. Women Q. 1999; 23(3): 519-536.

https://doi.org/10.1111/j.1471-6402.1999.tb00379.x

Weigard A, Loviska AM, Beltz A: Little evidence for sex or ovarian hormone influences on affective variability. Scientific Reports. 2021; 11, 20925. https://doi.org/10.1038/s41598-021- 
00143-7

大谷 尚: 質的研究の考え方 研究方法論からSCATによる分析まで. 名古屋大学出版会; 2019.

田中 東子: なぜ男性より女性のほうがインターネットで炎上しやすいのか「性らしくない女性 を罰したい」.2020. (accessed 22 December 2021). Reference Source

小山 耕平, 浅谷 公威, 榊剛史, et al::ネット炎上におけるユーザーの共振構造. The 33rd Annual Conference of the Japanese Society for Artificial Intelligence.

2019.

Competing Interests: No competing interests were disclosed.

Reviewer Report 09 December 2021

https://doi.org/10.5256/f1000research.78433.r100519

(c) 2021 Kawahata Y. This is an open access peer review report distributed under the terms of the Creative Commons Attribution License, which permits unrestricted use, distribution, and reproduction in any medium, provided the original work is properly cited.

\section{Yasuko Kawahata}

College of Social Relations, Department of Communication and Media Studies, Rikkyo University, Tokyo, Japan

イントロダクション・前文では、オンライン・ハラスメントに関しての発生起因における最新の動向に 関する研究、事例紹介などの論考が掲載されており、一般の方々を対象とした昨今のオンライン上にお けるリスクマネジメントに関する議論がまとめられているコレクティブ・インフォメーションとしての 役割を果たすだろうと考えました。

(1) 全体のレビュー

一方で、今回の記事はジャーナリストを対象にした比較的顕著な一例における事例であるかとも存じま す。

そういった面では、多くの課題が示唆できる論文でもあり、今後も議論が続くであろうオンライン・ハ ラスメントにおける問題解決の活路を提示する位置づけの論文としての役割も果たしていると考えてお ります。今回の議論ではジャーナリスト（Z 氏）の一例を元に議論を展開していきましたが、広範なメ ディア単位でも表出しつつある課題でもあり、ミクロな観点でも一般のコミュニティ内でもソーシャル ・ハラスメントとしてオンラインが利活用されるリスクは存在するため今後も議論を要する課題である と考えます。本稿では、分析対象としたSNS上のソースデータに関して被害者・加害者の両者のプライ バシーに配慮をした考察がされている点に関しても（編集部了承済み）、今後の本議論の展開の方法論 に関しての示唆も提示されており、より議論の深化に寄与されればと考えます。

(2) 追論すべきポイント

本稿に関連するトピックとして、2021年11月31日にプレスリリースされましたが、Twitter上における なりすましに関するポリシー・利用規約が改訂されたことが今後、本議論でもどのように取り扱われる 
か、有効に働きうるかは課題です。

“Twitter Safetyは「女性、活動家、反体制派、マイノリティコミュニティの一員に対し、過度に影響を 与える可能性がある」とし、ポリシーに違反する画像や動画がシェアされた場合、Twitterはそのメディ アを削除するとともにしかるべき強制的対応、たとえば当該ツイートを検索結果に表示されにくくした り、ツイートの削除対応をしたうえで投稿者に通知し、またTwitterはポリシーに違反しているユーザー アカウントを永久に凍結する権限もあるとしています。”意訳・引用元：

https://twitter.com/TwitterSafety, 参照：2021/12/02)

といった具体的な対策に関するケースも言及され、より一層本稿における議論は加速化すると考えてお ります。

主に、本稿でも示唆されている通り、ある“特定の個人”に不特定多数で、攻撃的な行為を行う、「成り 済まし」を行った上で誹謗中傷を「暗に行う」事例などといった、陰湿なソーシャル・ハラスメント行 為、所謂「ソーシャルポルノ」の事例も観測されております。

また、搾取対象に対して無許可にメディア化する行為、身体的特徵を揶揄する行為、反社会的行為、つ まりは個人の利益、日常行為を著しく害する行為などもSNS上で見受けられており、上述の引用のよう に注意喚起なども情報共有されつつある点ではプラットフォーム単位での環境改善は始まっているもの の、まだこれから課題解決に働きかけが必要となる要素が多くあります。

（3）本議論に関する今後の課題点、調査展望に関して

本稿における課題に関しては、オンライン・ハラスメントの手法がテキストなど文面・ショートメッセ 一ジで発露するものから、トラッキングが困難になりやすい画像、イラスト、映像でのソーシャルポル ノの暴露なども目立ってきている観点もあります。そのため、本論のようなケースに関して、さらに注 視、また注意喚起などが教育機関での情報共有もなされるべきだと考えております。特に画像・音声メ ディア・映像など拡散性の高いメディアとなるとさらなるソーシャルポルノのリスクが発生し、被害者 ・加害者周辺における事実確認などが困難にもなりやすく隠蔽工作なども進みやすいところで、泣き寝 入りとなるケースに関してもSNS上で被害者の声として観測されております。

そのため、まずは問題意識の共有の契機は必要であると考えます。（上記のケースに関してはレビュワ 一による匿名調査の元での見解。）そういった面で、学術的価値がある内容であると考えます。今後、 より対策に講じるべき課題であり、これら問題解決をする際のSNS上での議論の過熱化、また加害者・ 被害者に対する合理的配慮、紛争解決の議論などを始めていくべきでもあり、インターネット上の違法 ・有害情報に対する対応（プロバイダ責任制限法）の改正なども本年度行われた観点も踏まえ、より学 術的な議論も展開できればと考えるところです。また、本議論を展開するにおいてSNS上における「リ スクマネジメント」など教育関係者での情報共有など、唐突な有害情報の暴露のリスクまで考慮にいれ た議論、対応などもより必要なるかと考えます。そういった面で、本論における議論・論文は情報共有 をする面でも有益に働く内容かとも存じます。

(4) まとめ

本稿でも触れている通り、ハラスメント防止策に関する提案に関して提示しているところ、インシデン トの事例収集も必要になっていると考えます。

特に、裁判など起こす力、知識を持たない若年層、または弱者など搾取対象とされやすい対象に対する インシデントは今後も発生しうると考えるため、これらの問題収集、対策の議論など情報共有、コミュ ニティ形成を推し量っていく必要もあるかと存じます。特に海外サーバーにあるプラットフォームにお けるインシデント・紛争解決は論文中でも触れてあるように解決までに時間を有することが多く、実効 的な防止策に関する議論に関して継続的な試み、論文などにおけるジャーナリズムとしての意見共有の 機会も必要かと考えるところ、本稿が一つの議論の深化に接続すればと願っております。

\section{参考文献}

Twitter, Inc.: なりすましに関するポリシー.n.d. available at: https://help.twitter.com/ja/rules-andpolicies/twitter-impersonation-policy. Accessed 2021/12/02. 
総務省: インターネット上の違法・有害情報に対する対応（プロバイダ責任制限法）.n.d. available at: https://www.soumu.go.jp/main_sosiki/joho_tsusin/d_syohi/ihoyugai.html

本研究は明確かつ正確に提示されたものであり、最新の文献を引用していますか。 はい

研究設計は適切で学術的価値がありますか。 はい

方法と分析について第三者による再現が可能となるよう十分な詳細が提示されていますか。 はい

（該当する場合は要回答）統計分析および解釈は適切ですか。 対象外（統計を使っていない

結果の基礎となるソースデータはすべて入手可能で再現性を十全に保証していますか。 ソースデータは不要

結論は結果により妥当な裏付けを得ていますか。 はい

Competing Interests: No competing interests were disclosed.

Reviewer Expertise: SNS，社会情報, メディア社会

I confirm that I have read this submission and believe that I have an appropriate level of expertise to confirm that it is of an acceptable scientific standard.

Author Response 13 Jan 2022

Aki Tonami

川畑先生

査読コメントをいただき、誠にありがとうございます。 いただいたコメントは、どれも大変重要、かつ今後の研究の発展に向けて参考になる指摘である と存じます。(2)(3)の追論のポイントに関しましては、今後の課題として、クロスプラットフォ 一ムで行われるハラスメントや、なりすまし、テキスト以外を使用したハラスメント行為の検討 が必要として、追記いたしました。

Competing Interests: No competing interests were disclosed. 
The benefits of publishing with F1000Research:

- Your article is published within days, with no editorial bias

- You can publish traditional articles, null/negative results, case reports, data notes and more

- The peer review process is transparent and collaborative

- Your article is indexed in PubMed after passing peer review

- Dedicated customer support at every stage

For pre-submission enquiries, contact research@f1000.com 